\title{
TÃO LINDA COMPOSIÇÃO
}

Bruno Dariva 49

Recebido: $23 / \mathrm{dez} / 2019$

Aceite: $27 / \mathrm{jan} / 2020$

DOI: https://doi.org/10.29327/2.1373.2.1-11

A encomenda estava finalmente no meio da sala. Carlos não estava certo quanto ao local que o gigante instrumento ocuparia em meio às mobílias; com uma escolha intuitiva, resolveu arrumá-lo no cômodo mais espaçoso. O grande piano precisou ser içado acima do muro de sua pequena casa, em frente à movimentada avenida Dom João. Por sorte, o imóvel contava com uma garagem de bom tamanho, de modo que o trabalho foi facilitado, e Carlos teria mais tempo para aprender alguma coisa naquela tarde.

Era um luxuoso piano de armário francês. Le Blanc. Carlos havia consultado os mais variados especialistas: as indicações eram unânimes, não existia nada melhor no mercado. Inicialmente, tinha pensado em adquirir um teclado. Refutou a ideia rapidamente - não era instrumento de verdade, eles diziam. Se quisesse de fato aprender, não poderia se render às modernidades eletrônicas; precisaria de um instrumento robusto e acústico. Os quase 90 mil reais seriam um tiro certeiro, um investimento para a vida toda, não havia dúvida. Os especialistas não têm dúvidas.

Com o tempo nublado, Carlos vislumbrou uma tarde perfeita: conseguiria praticar o básico das mais lindas sonatas de Beethoven. Talvez sobrasse tempo para dar uma olhada em Chopin. Não podia desperdiçar os minutos. 90 mil reais, ele pensava. Embora o preto lustroso e os detalhes em dourado lhe chamassem constantemente a atenção,

\footnotetext{
49 Mestrando em Letras Universidade Federal o Rio Grande do Sul. Grupo de pesquisa: Narratologia e Intermidialidade: Novas Mídias, Novas Abordagens. E-mail de contato: brunodariva@msn.com ORCiD https://orcid.org/0000-0001-5794-7017
} 


\section{Revista Interdisciplinar em Estudos de Linguagem}

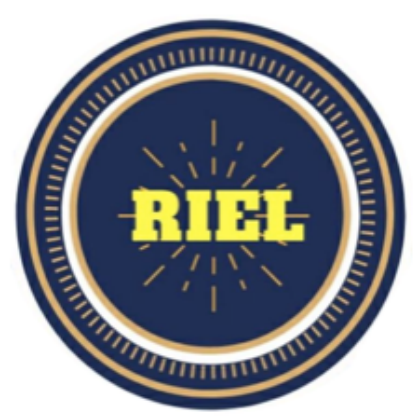

não cogitou admirar cuidadosamente a beleza do instrumento, poderia fazer isso mais tarde, à noite, em meio à calmaria e ao silêncio. No momento em que sentou de frente para as teclas, porém, sentiu um misto de apreensão e desconforto; alguma coisa não estava em harmonia. Parou por um instante e esticou os músculos do pescoço como um cão quando ouve latidos à distância; fosse um animal, suas orelhas estariam eretas. $\mathrm{O}$ desequilíbrio vinha da rua. Um aglomerado de homens acompanhava o trabalho de um senhor experiente que manejava sua britadeira sobre a calçada do lado oposto. Uma convulsão de encontros entre uma pequena peça de metal e o chão de concreto produzia um som tectônico e repetitivo. Não era, afinal, uma tarde perfeita. Carlos impacientemente se levantou e foi até a janela observar o procedimento. Questionou-se sobre a ordem dos fatos: teria a britadeira começado a trabalhar somente naquele momento?

Aguardou por aproximadamente uma hora até que não ouvisse mais indícios de trabalho na calçada. Durante esse tempo, houve pausas de poucos minutos, mas Carlos tinha medo: caso explorasse a capacidade musical de seu Le Blanc, o som francês aveludado poderia ser interrompido a qualquer instante e condenado à desgraça. Não poderia arriscar. Para ele, a inconstância sempre foi um pecado capital; antes uma ordem de ruídos constantes - que às vezes chamava de silêncio - do que qualquer mínima interrupção sonora destoante. Diante da situação, o temor era evidente. Estaria o trabalho terminado? Não estaria o senhor apenas descansando para em seguida retornar? Foi à janela e não observou movimento na calçada. Não era o suficiente. Precisava ter certeza. Saiu à porta e mirou os estabelecimentos vizinhos. Lá estava ele, um senhor de uniforme amarelo, no Armazém da Neusa. Necessitava perguntar.

"O senhor ainda vai usar a britadeira?"

"Vou não, meu jovem".

Não conseguiu conter o raro sorriso e respondeu com um agradecimento de timbre suave. Retornou às pressas.

Calmamente sentou na banqueta com as costas eretas. Sentiu a harmonia pela primeira vez naquela tarde. Retirou a partitura da sonata $\mathrm{n}^{\circ} 14$ que havia guardado dentro da gaveta de seu assento dourado. Começou o primeiro andamento com a leveza e 


\section{Revista Interdisciplinar em Éstudos de Linguagem}

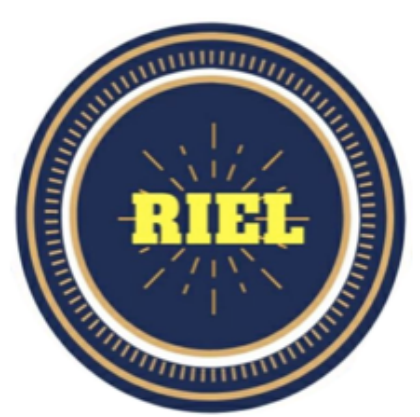

sensibilidade que faziam jus ao instrumento que o acompanhava. Ludwig não teria motivos para se decepcionar, pensou. A fantasia melancólica proporcionada pela fusão de sentimentos entre Carlos e seu Le Blanc ressoava pela sala de estar e parecia acalmar tudo à sua volta; a vida na rua parecia a qualquer momento abrir a janela para possibilitar a propagação do rico som pelos labirintos acinzentados.

Pobre Carlos.

Os infortúnios não se curvam a dinheiro ou a belas melodias. A vitalidade da rua não precisou abrir a janela, pois o tec tec da britadeira acabara de atingir Carlos em cheio.

Soltou um grito de raiva e decepção. Lágrimas começavam a escorrer de seus olhos. Praguejava contra o senhor de amarelo. "Mentiroso, mentiroso, mentiroso!". Saiu às pressas à procura do velho infeliz; não tinha mais esperanças de restabelecer a consonância que havia antes atingido. Abriu a porta esbravejando ofensas desafinadas para o outro lado da rua, ao que o velho reagiu assustado balbuciando algumas palavras em uma tentativa de explicação. Os sons inaudíveis somavam-se a gestos de desespero enquanto Carlos caminhava apressadamente ao seu encontro. Pobre Carlos, odiava ser interrompido. A melancolia da sonata $\mathrm{n}^{\circ} 14$ ainda ressoava em sua cabeça quando uma buzina estridente em dó maior embaralhou as notas de vez; a freada que se seguiu compôs em conjunto uma abertura inesperada. Carlos desabou. $\mathrm{O}$ toque da pele humana com o asfalto deu um tom aveludado à sinfonia. Estagnado ao chão, ouviu uma sirene de ambulância em ré menor se aproximando. A britadeira estava em silêncio. Jamais havia ouvido tão linda composição. 